\title{
Biological Deacidification of Musts Induced by Yeasts or Malolactic Bacteria and the Effect on Wine Quality
}

\author{
T.J. van Rooyen ${ }^{\text {a) }}$ and R.P. Tracey ${ }^{\text {b) }}$ \\ a) Department of Oenology. University of Stellenbosch, 7600 Stellenbosch, Republic of South Africa. \\ b) Viticultural and Oenological Research Institute, Private Bag X5026, 7600 Stellenbosch, Republic of South Africa.
}

Submitted for publication: September 1987

Accepted for publication: October 1987

Keywords: Deacidification. Yeasts,Schizosaccharomyces, Saccharomyces, Malolactic fermentation,Leuconostoc oenos, Wine quality

\begin{abstract}
This study investigated the possible use of Schizosaccharomyces pombe and Schizosaccharomyces malidevorans for deacidification of red wines during alcoholic fermentation, in comparison with existing deacidification practices of induced or spontaneous malolactic fermentation (MLF) in South Africa. In red must, the effect of these yeasts on alcoholic fermentation rate, rate of $\mathrm{L}$-malic acid removal, as well as the effect of mixed cultures with Saccharomyces cerevisiae at different inoculum concentrations and sizes of inocula on wine quality was investigated. In white must, the effect of pure culture inocula and temperature on wine quality and production of volatile bouquet substances was also studied. Both Schizosaccharomyces spp. were found to deacidify normal concentrations of $L$-malic acid in musts effectively at higher growth temperatures, but the ability of Schiz. pombe was inhibited by high concentrations of Lmalic acid which was not $\mathrm{pH}$ dependent. Certain key volatile fermentation bouquet compounds were produced in very low quantities, which seems to be the reason for poor sensory quality wines produced by Schizosaccharomyces.
\end{abstract}

The need for deacidification of wine is not the same in all countries. Northern Hemisphere wine producing areas, including Eastern USA (Munyon \& Nagel, 1977), more often have the need for deacidification because of too high acidity and too low $\mathrm{pH}$ due to cold weather and insufficient ripening of grapes. In Southern Hemisphere countries, the need is more often to acidify musts or wines to create a good acid balance with the correct amount of tartness. However, a survey of the incidence of malolactic fermentation (MLF) in South African red table wines has shown that spontaneous MLF occurred in $27,5 \%$ of the cases within a short period after completion of alcoholic fermentation and in most cases $(66,2 \%)$, had been completed before bottling (Van Wyk, 1976). Most oenologists are of opinion that biological deacidification should be encouraged by adapting wine-making technology and by inducing bacteriological deacidification by starter cultures, in order to stabilize such wines biologically to prevent uncontrolled deacidification after bottling.

In contrast to MLF by bacteria, yeasts belonging to the genera Schizosaccharomyces convert grape sugar and malic acid to ethanol and carbon dioxide (Dittrich, 1963; Mayer, 1963). Although many studies have been undertaken dealing with wine deacidification by $S c h i-$ zosaccharomyces spp. as basis (Beelman \& Gallander, 1979), most studies were conducted using Schiz. pombe. The reason Schiz. malidevorans was not studied to the same extent could be the formation of copious amounts of hydrogen sulphide during fermentation (Rankine \& Fornachon, 1964; Rankine, 1966).

The amount of deacidification depends not only on the Schizosaccharomyces specie and strain (Benda \& Schmitt, 1969; Beelman \& Gallander, 1979), but also on temperature. The optimum deacidification temperature for Schiz. pombe was found to be $20^{\circ} \mathrm{C}-25^{\circ} \mathrm{C}$ (Spirov et al., 1982). Dittrich (1963a) found a direct relationship between temperature and fermentation rate as well as deacidification rate. However, $35^{\circ} \mathrm{C}$ was found to be above the optimum temperature and fermentations were not completed. He states $30^{\circ} \mathrm{C}$ to be nearer the optimum temperature for Schiz. pombe. Contradictory to this, Benda and Schmitt (1966) found no difference in the degree of malic acid decomposition at $11^{\circ} \mathrm{C}$ and $20^{\circ} \mathrm{C}$. This could have been due to both temperatures being far below the optimum for Schiz. pombe.

Beelman and Gallander (1979) concluded from work by Rankine (1966) and Peynaud et al. (1964) that malic acid utilization was $\mathrm{pH}$ dependent, but added that additional information is needed to verify that the amount of L-malic acid decomposed is inversely related to $\mathrm{pH}$. It is possible that the lower limit of the $\mathrm{pH}$ range would be approx. 2,5, at which Yang (1973b) found only $70 \%$ utilization by Schiz. pombe. The high deacidification ability of Schizosaccharomyces of highly acid musts has been a great contributor to the betterment of the quality of these wines, as compared to the less deacidified wines fermented by Saccharomyces (Yang, 1973a; Ethiraj \& Suresh, 1978). However, musts that were not excessively acidic were found to be over - deacidified, which could result in inferior wine quality (Yang, 1973a). The work by Rankine (1966) in Australia, indicated the possible use of selected yeasts for either maximum or minimum decomposition of L-malic acid.

Several researchers have found inferior quality of wines after fermentation with Schizosaccharomyces (Benda \& Schmitt, 1966; Spirov et al., 1982; Delfini et al., 1983; Delfini \& Pagliara, 1979). Nonomura et al., 1968 (Beelman \& Gallander, 1979) found wines from Schizosaccharomyces better tasting than wines fermented with true yeast, although these wines had inferior bouquets. However, many researchers have reported wines which did not differ in sensory quality from control treatments or Saccharomyces (Ethiraj \& Suresh, 1978; Yang, 1973a; Ethiraj, Suresh \& Onka- 
rayya, 1983; Svejcar, 1970; Benda \& Schmitt, 1979). Beelman and Gallander (1979) also felt that most studies concerning wine deacidification by Schizosaccharomyces had incomplete sensory evaluation data with statistical analyses. Except for reports by Rankine and Fornachon (1964) as well as Rankine (1966), concerning $\mathrm{H}_{2} \mathrm{~S}$ production by Schiz. malidevorans, an aspect lacking in most research papers as to the lower sensory quality of Schizosaccharomyces wines, has been an accurate description or identification of the aroma or flavour deficiency of such wines. Carre et al. (1983) reported concentrations of groups of volatile fermentation bouquet substances, but did not correlate these with statistically analyzed sensory evaluation data.

Initially the use of mixed cultures was researched in order to attain the desired amount of deacidification (Dittrich, 1963a; Rankine, 1966), as well as to minimize unpleasant sensory characteristics produced by Schizosaccharomyces (Carre et al., 1983; Ethiraj et al., 1983). No report could be found in the available literature of comparative tests which included induced MLF by selected malo-lactic bacteria, in order to compare both deacidification abilities and rates as well as effect on sensory quality. To date, no research data on Schizosaccharomyces has been published by South African researchers. The aim of this work was to evaluate the possible use of Schiz. pombe and Schiz. malidevorans separately and in combination with Saccharomyces cerevisiae for biological stabilization of red wines, in comparison with existing biological deacidification practices in South Africa. Because of seemingly contradictory reports concerning the negative effects of Schizosaccharomyces fermentation on the production of bouquet substances, this was also investigated in white grape juice.

\section{MATERIALS AND METHODS}

Organisms: Saccharomyces cerevisiae strain WE 14 was obtained as active dried wine yeast from the producer. Schizosaccharomyces pombe strain CBS 5682 and Schiz. malidevorans strain CBS 5557 were obtained from Prof. J. P. van der Walt, CSIR, Pretoria, South Africa. Both Schizosaccharomyces spp. are the type species. Schizosaccharomyces malidevorans was initially isolated from wine by Rankine and Fornachon (1964) and deposited at the Centraalbureau voor Schimmelcultures in Delft, Netherlands. Leuconostoc oenos (strain LO) was obtained from the VORI culture collection.

Inoculum preparation: Saccharomyces cerevisiae was rehydrated and inoculated according to the manufacturer's instructions. Both Schizosaccharomyces spp. were cultured in 11 Erlenmeyer flasks containing $500 \mathrm{ml}$ sterile Colombar must on a shaker at $25^{\circ} \mathrm{C}$ for 18 hours. The $L$. oenos strain was grown in Tomato Juice Broth for 5 days at $25^{\circ} \mathrm{C}$.

Vinification and must treatments: Cabernet Sauvignon grapes from the same vineyard (Welgevallen Experimental Farm, University of Stellenbosch) were used in 1984 (sugar $23,4^{\circ} \mathrm{B}$; titratable acidity $5,6 \mathrm{~g} / \mathrm{l} ; \mathrm{pH}$ 3,8 ) and in 1985 (sugar $21^{\circ} \mathrm{B}$; titratable acidity 5,$2 ; \mathrm{pH}$ $3,9)$. The titratable acidity was adjusted to 7,0 and 7,5 g/l with L-Tartaric acid (Merck 804) in 1984 and 1985 respectively.
In the 1984 season, the effect of the following treatments at $25^{\circ} \mathrm{C}$ on the quality of Cabernet Sauvignon wine was studied: alcoholic fermentation by Sacch. cerevisiae and spontaneous MLF or MLF induced by inoculation with $L$. oenos after pressing the skins at half of the initial sugar concentration; alcoholic fermentation and malic acid deacidification by Schiz. pombe or Schiz. malidevorans.

In the 1985 season Sacch. cerevisiae was used for all treatments of Cabernet Sauvignon except one, where Schiz. pombe was used. In the control treatments MLF was allowed to occur spontaneously or was induced by L. oenos. Musts were treated in the following ways to study the effect of time of inoculation $\left(11^{\circ} \mathrm{B}\right.$ and $\left.1{ }^{\circ} \mathrm{B}\right)$ and size of inoculum $(2 \%, 5 \%, 10 \% \mathrm{v} / \mathrm{v})$ of Schiz. pombe on deacidification and wine quality. Grapes were crushed, destemmed and separated. The juice was divided on a mass basis before adding the skins to the juices. Samples were drawn regularly, treated with $\mathrm{NaF}$, frozen and stored until analyses could commence.

In the second experiment in 1985, Chenin blanc grapes from Welgevallen, as well as a second harvest of Chenin blanc from the VORI vineyard were crushed and destemmed with addition of $60 \mathrm{mg} / l \mathrm{SO}$, settled overnight, mixed and divided to obtain three lots with increasing malic acid concentrations. The $\mathrm{pH}$ was adjusted to $3,42+/-0,04$ by reduction of the tartrate content with $\mathrm{CaCO}_{3}$ (Munyon \& Nagel, 1977). After mixing and adjustments, the lots had average L-malic acid contents of $7,93,11,89$ and $15,83 \mathrm{~g} / \mathrm{l}$ respectively. These lots were subdivided into seven $6,5 \mathrm{l}$ duplicate sublots in $10 l$ stainless steel canisters fitted with fermentation locks. After inoculation with the various yeasts, canisters were placed in a fermentation room maintained at $21^{\circ} \mathrm{C}$. Samples were taken at regular intervals during fermentation and treated in the same manner as the first experiment.

For the third experiment the Chenin blanc treatment which contained 7,93 $\mathrm{g} / \mathrm{l} \mathrm{L}$-malic acid was repeated in order to study the effect of yeast inoculum (Sacch. cerevisiae, Schiz. pombe and Schiz. malidevorans) and fermentation temperature $\left(15^{\circ} \mathrm{C}\right.$ and $\left.21^{\circ} \mathrm{C}\right)$ on the quality of Chenin blanc wine.

Malic and lactic acid analyses: Malic acid was detected qualitatively by paper chromatography (Kunkee, 1968) for the 1984 Cabernet Sauvignon experiment. All other malic acid analyses, together with lactic acid were done by high performance liquid chromatography (HPLC). The method of Schwarzenbach (1982) was used with the following modifications: column temperature $40^{\circ} \mathrm{C}$ (constant); mobile phase, $0,013 \mathrm{~N} \mathrm{H}_{3} \mathrm{PO}_{4}$. A UV detector (KNAUER Spekralfotometer Model 87.00) was used for detecting eluting peaks, which were quantified by means of an APPLE IIe fitted with Chromatochart (Interactive Microware Inc. PA 16801) chromatography software (Van Rooyen \& Van Wyk, 1986).

GC analysis: Quantitative determination of volatile fermentation bouquet substances was done by the method described by Marais (1986).

Sensory analysis: Wine quality was determined by a panel of 12 experienced judges, using the nine point score card (Tromp \& Conradie 1979). In order to eliminate possible sensory differences in acidity due to deacidification and to compare Schizosaccharomyces and 
Saccharomyces treatments for Cabernet Sauvignon and for Chenin blanc wines, a calculated amount of DLmalic acid was added 24 hours prior to judging. This amount was determined as the difference in total titratable acidity between the Saccharomyces and the other treatments.

Statistical analysis: Friedman's non - parametric twoway analysis of variance was used for wines tasted by the nine point score card. All experiments were carried out in duplicate.

\section{RESULTS AND DISCUSSION}

Fermentation rates: It is evident from Table 1 that temperature had a profound effect on the alcoholic fermentation ability of both Schizosaccharomyces spp. in Cabernet Sauvignon and Chenin blanc musts. It is also clear that $25^{\circ} \mathrm{C}$ is closer to the optimum fermentation temperature for Schizosaccharomyces spp. than $15^{\circ} \mathrm{C}$. It has been shown by various authors that the growth temperature for Schizosaccharomyces spp. is higher than for Sacch. cerevisiae. Peynaud and Sudraud, 1964 (Beelman \& Gallander, 1979) found maximum growth at approx. $35^{\circ} \mathrm{C}$. Yang (1973) reported faster alcoholic fermentation rates by Sacch. cerevisiae than Schiz. pombe at $12,8^{\circ} \mathrm{C}$ for white musts. Spirov et al. (1982) showed $25^{\circ} \mathrm{C}$ to be near optimum growth temperature for Schiz. pombe and Dittrich (1963) found the highest alcoholic fermentation rate at $25^{\circ} \mathrm{C}$. Except for the Sacch. cerevisiae alcoholic fermentation in the 1984 Cabernet Sauvignon must, which took 43 days, all fermentations finished within an expectedly reasonable time. At this relatively high temperature of $25^{\circ} \mathrm{C}$, both $\mathrm{Schi}$ - zosaccharomyces spp. had a fermentation rate approximately double that of Sacch. cerevisiae. In the Chenin blanc musts, Sacch. cerevisiae fermented at more than twice the rate of both Schizosaccharomyces spp. at both $15^{\circ} \mathrm{C}$ and $21^{\circ} \mathrm{C}$. This illustrates the rate-enhancing effect of high temperature on fermentation by Schizosaccharomyces and parallels the results of Dittrich (1963a), who found that high fermentation temperature benefited the growth of Schiz. pombe such that after fermentation in a mixed culture with Sacch. cerevisiae, Schiz. pombe was the predominant yeast.

Small differences were noted in the fermentation rates with addition of Schiz. pombe to the fermenting 1985 Cabernet Sauvignon musts by Sacch. cerevisiae. These differences were probably not due to the addition itself, as the addition was done at a late stage and the pure Schiz. pombe alcoholic fermentation rate did not differ from that by Sacch. cerevisiae.

\section{Malic and lactic acid concentrations:}

Cabernet Sauvignon 1984: All treatments took 63 days for completion of deacidification, except for Schiz. malidevorans which took 42 days.

Cabernet Sauvignon 1985: Schiz. malidevorans was omitted after the 1984 experiment because of the poorer wine quality (Fig. 4). Figure 1 shows the concentrations of malic and lactic acids of the three deacidification treatments. It is evident that malic acid was metabolized soon after the second day (when skins were pressed at $11^{\circ} \mathrm{B}$ ). The slowest rate of malic acid removal was in the case of spontaneous MLF, where no exogenous malic acid metabolizing organisms were added. In spite of this, total removal of malic acid took

TABLE 1

Fermentation rates of various must treatments by Saccharomyces cerevisiae, Schizosaccharomyces pombe and Schiz. malidevorans.

\begin{tabular}{|c|c|c|c|c|}
\hline \multirow[t]{2}{*}{ Treatment } & \multicolumn{2}{|c|}{1984} & \multicolumn{2}{|c|}{1985} \\
\hline & $\begin{array}{l}\text { Time for } \\
\text { completion of } \\
\text { alcoholic } \\
\text { fermentation } \\
\text { (days) }\end{array}$ & $\begin{array}{c}\text { Fermentation } \\
\text { rate } \\
\text { (days) }\end{array}$ & $\begin{array}{l}\text { Time for } \\
\text { completion of } \\
\text { alcoholic } \\
\text { fermentation } \\
\text { (days) }\end{array}$ & $\begin{array}{c}\text { Fermentation } \\
\text { rate } \\
\text { (days) }\end{array}$ \\
\hline $\begin{array}{l}\text { Cabernet Sauvignon } 25^{\circ} \mathrm{C}(1984) \\
\text { Sacch. cerevisiae }+ \text { spontaneous MLF } \\
\text { Sacch. cerevisiae }+\mathrm{L} \text {. oenos induced MLF } \\
\text { Schiz. pombé } \\
\text { Schiz. malidevorans } \\
\text { Cabernet Sauvignon } 21^{\circ} \mathrm{C}(1985) \\
\text { Schiz. pombe } \\
\text { Sacch. cerevisiae }+ \text { spontaneous MLF } \\
\text { Sacch. cerevisiae }+\mathrm{L} \text {. oenos induced MLF } \\
\text { Sacch. cerevisiae }+2 \% \text { Schiz. pombe at } 11^{\circ} \mathrm{B} \\
\text { Sacch. cerevisiae }+5 \% \text { Schiz. pombe at } 11^{\circ} \mathrm{B} \\
\text { Sacch. cerevisiae }+10 \% \text { Schiz. pombe at } 11^{\circ} \mathrm{B} \\
\text { Sacch. cerevisiae }+2 \% \text { Schiz. pombe at } 1^{\circ} \mathrm{B} \\
\text { Sacch. cerevisiae }+5 \% \text { Schiz. pombe at } 1^{\circ} \mathrm{B} \\
\text { Sacch. cerevisiae }+10 \% \text { Schiz. pombe at } 1^{\circ} \mathrm{B} \\
\text { Chenin Blanc } 15^{\circ} \mathrm{C}(1985) \\
\text { Sacch. cerevisiae } \\
\text { Schiz. pombe } \\
\text { Schiz. malidevorans } \\
\text { Chenin Blanc } 21^{\circ} \mathrm{C}(1985) \\
\text { Sacch. cerevisiae } \\
\text { Schiz. pombe } \\
\text { Schiz. malidevorans }\end{array}$ & $\begin{array}{l}43 \\
43 \\
17 \\
23\end{array}$ & $\begin{array}{l}0,53 \\
0,53 \\
1,35 \\
1,00\end{array}$ & $\begin{array}{r}31 \\
31 \\
27 \\
31 \\
31 \\
31 \\
31 \\
27 \\
24 \\
\\
12 \\
27 \\
31 \\
\\
7 \\
18 \\
17\end{array}$ & $\begin{array}{l}0,69 \\
0,69 \\
0,79 \\
0,69 \\
0,69 \\
0,69 \\
0,69 \\
0,79 \\
0,89 \\
1,87 \\
0,83 \\
0,72 \\
\\
3,01 \\
1,15 \\
1,21\end{array}$ \\
\hline
\end{tabular}




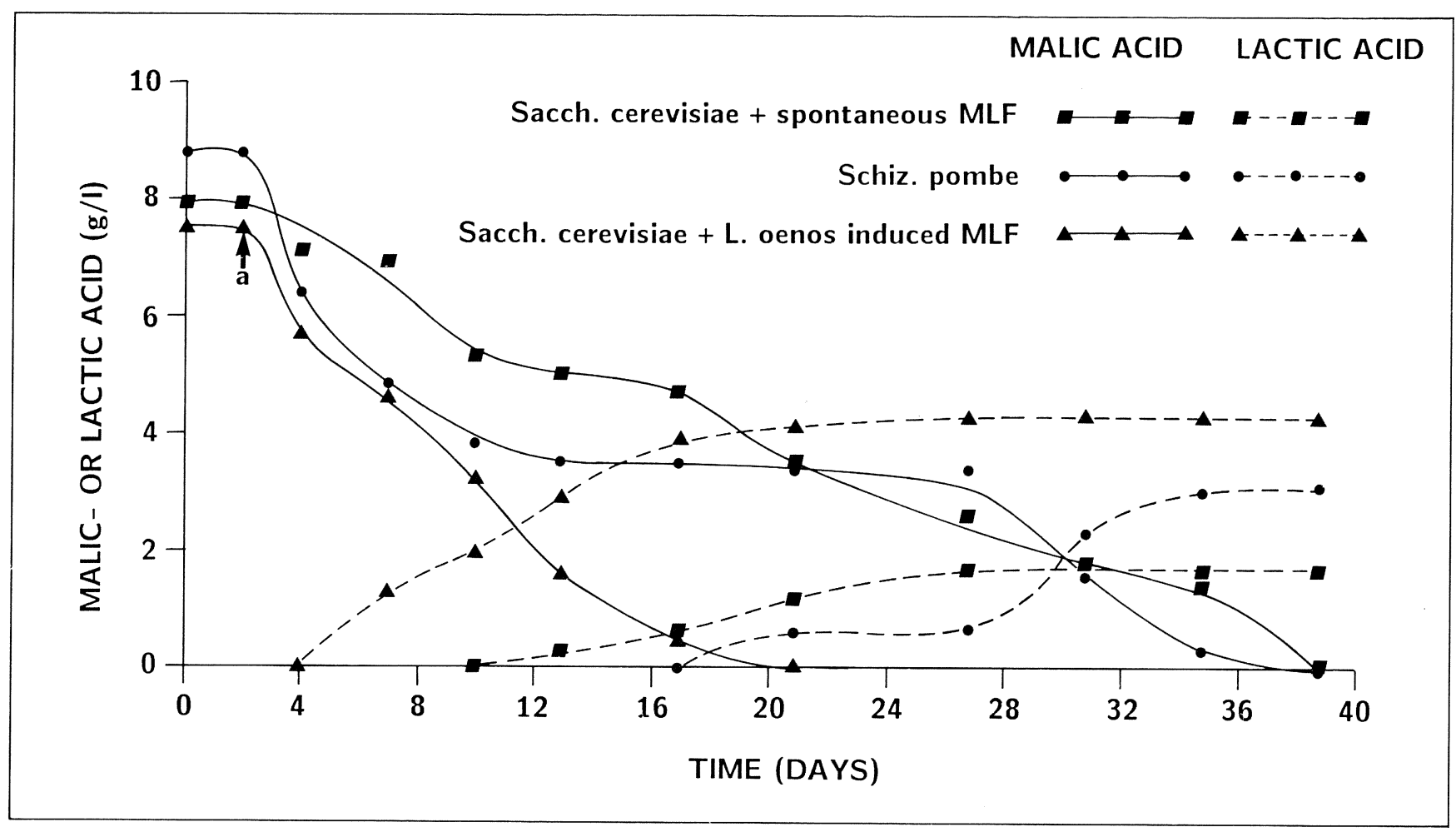

FIG. 1

Concentrations of malic and lactic acids in Cabernet Sauvignon musts deacidified by three different treatments.

as long as for the Schiz. pombe treatment. It is evident that $L$. oenos was most effective in reducing the malic acid content (21d), with the highest average daily rate of malic acid removal (Table 2), starting immediately after inoculation on the third day. From Fig. 1 it can be seen that production of lactic acid from malic acid started soon thereafter and of the three treatments, the most lactic acid was produced by $L$. oenos. It seems as if only half of the initial malic acid content was metabolized by Schiz. pombe after ten days, followed by a lag phase during which lactic acid started being produced. Of all treatments, Schiz. pombe had the highest rate of malic acid removal to half the initial concentration (Table 2), but was not capable of total metabolization of the malic acid present in the must. As Schizosaccharomyces spp. produce ethanol from malic acid and not lactic acid (Dittrich, 1963b), the natural malic acid bacteria must have grown to such an extent as to be able to metabolize the malic acid. This is apparent in the smaller final lactic acid concentration in comparison to the L. oenos treatment.

In contrast to this, the spontaneous MLF treatment (Fig. 1) produced even less lactic acid, which could be an indication of natural malic acid-metabolizing yeasts' activity in this must, of which the natural occurrence in newly fermented wines has been reported on (Van Zyl \& Du Plessis, 1961). Delfini, Torreggiani and Ottina (1983) reported epidemic proportions of naturally occurring Schizosaccharomyces yeasts during the previous vintage which they ascribed to unusually high environmental temperatures. As South Africa is a Southern Hemisphere country, unusually high temperatures for Italy could well be within normal South
African harvest time temperatures, where crushed grapes at $35^{\circ} \mathrm{C}$ are frequent.

Carre et al. (1983) advocated the possible use of Schizosaccharomyces spp. for deacidification of wine by addition towards the end of alcoholic fermentation to reduce adverse organoleptic consequences. They reported a considerable deacidification by this method. In our experiments this seems as effective as a pure culture addition of Schiz. pombe before alcoholic fermentation (Table 2). Addition of different sizes of Schizosaccharomyces inocula at different stages during alcoholic fermentation had no marked effect on the time for complete removal of malic acid. According to Beelman and Gallander (1979), true wine yeasts tend to outgrow the slow fermenting Schizosaccharomyces and this seems to have been the case in our experiment (Table 2).

Figure 2 shows a representative graph of malic and lactic acid concentrations for a $5 \%$ addition of Schiz. pombe at $11^{\circ} \mathrm{B}$ and $1{ }^{\circ} \mathrm{B}$ during alcoholic fermentation. A similar phenomenon can be observed as in Fig. 1, viz. a reduction in the malic acid concentration up to approximately half of the initial concentration, followed by a lag phase and the final reduction to zero concentration, during which time production of lactic acid started and increased to a maximum level. Benda and Schmitt (1966), who measured total titratable acidity (TTA) in Riesling must during fermentation, found a sudden drop in TTA for treatments with Schiz. pombe at $11^{\circ} \mathrm{C}$ as well as $20^{\circ} \mathrm{C}$, followed by a period of slow decrease in TTA. All combined treatments of Saccharomyces and Schizosaccharomyces exhibited the same tendency of a lower rate of malic acid utilization 
TABLE 2

Time for, and rate of malic acid removal from Cabernet Sauvignon (1985) must and wine by spontaneous MLF, induction with Leuconostoc oenos or several treatments with Schizosaccharomyces pombe.

\begin{tabular}{|c|c|c|c|c|c|}
\hline Treatments & $\begin{array}{l}\text { Initial } \\
\text { malic acid } \\
\text { concentra- } \\
\text { tion } \\
(\mathrm{g} / l)\end{array}$ & $\begin{array}{l}\text { Time for } \\
\text { complete } \\
\text { removal of } \\
\text { malic acid } \\
\text { (days) }\end{array}$ & $\begin{array}{l}\text { Average } \\
\text { daily rate } \\
\text { of malic } \\
\text { acid } \\
\text { removal } \\
(\mathrm{g} / \mathrm{l} / \mathrm{d})\end{array}$ & $\begin{array}{l}\text { Rate of } \\
\text { malic acid } \\
\text { removal: } \\
\text { initial to } \\
\text { half con- } \\
\text { centration } \\
(\mathrm{g} / \mathrm{l} / \mathrm{d})\end{array}$ & $\begin{array}{l}\text { Rate of } \\
\text { malic acid } \\
\text { removal: } \\
\text { half } \\
\text { to zero } \\
\text { concentration } \\
(\mathrm{g} / / \mathrm{d})\end{array}$ \\
\hline $\begin{array}{l}\text { Schizosaccharomyces pombe } \\
\text { Sacch. cerevisiae }+ \text { spontaneous MLF } \\
\text { Sacch. cerevisiae }+ \text { L. oenos induced MLF } 11^{\circ} \mathrm{B} \\
\text { Sacch. cerevisiae }+2 \% \text { Schiz. pombe at } 11^{\circ} \mathrm{B} \\
\text { Sacch. cerevisiae }+5 \% \text { Schiz. pombe at } 11^{\circ} \mathrm{B} \\
\text { Sacch. cerevisiae }+10 \% \text { Schiz. pombe at } 11^{\circ} \mathrm{B} \\
\text { Sacch. cerevisiae }+2 \% \text { Schiz. pombe at } 1^{\circ} \mathrm{B} \\
\text { Sacch. cerevisiae }+5 \% \text { Schiz. pombe at } 1^{\circ} \mathrm{B} \\
\text { Sacch. cerevisiae }+10 \% \text { Schiz. pombe at } 1^{\circ} \mathrm{B}\end{array}$ & $\begin{array}{l}8.757 \\
7.887 \\
7.495 \\
7.870 \\
7.890 \\
7.878 \\
7.296 \\
7.128 \\
7.687\end{array}$ & $\begin{array}{l}39 \\
39 \\
21 \\
35 \\
39 \\
35 \\
39 \\
39 \\
39\end{array}$ & $\begin{array}{l}0,225 \\
0,202 \\
0,350 \\
0,225 \\
0,202 \\
0,225 \\
0,187 \\
0,183 \\
0,197\end{array}$ & $\begin{array}{l}0,461 \\
0,219 \\
0,416 \\
0,179 \\
0,164 \\
0,164 \\
0,159 \\
0,119 \\
0,202\end{array}$ & $\begin{array}{l}0.148 \\
0,188 \\
0.312 \\
0,303 \\
0.063 \\
0.358 \\
0.228 \\
0.396 \\
0.192\end{array}$ \\
\hline
\end{tabular}

from initial to half concentration and an increase in the rate from half to zero concentration (Table 2). This increase coincided with lactic acid production, which indicates malolactic bacterial activity. Benda and Schmitt (1966) also found a similar phenomenon in their Rieslaner must, where approx. $2 \mathrm{~g} / l$ TTA reduction occurred by Schizosaccharomyces after 30 days. After two years, though, the reduction was $7,8 \mathrm{~g} / l$, with a coinciding increase of $6 \mathrm{~g} / \mathrm{l}$ of lactic acid.

The decrease in malic acid during fermentation can be ascribed partly to the ability of Sacch. cerevisiae strain WE 14, which was found capable of utilizing $20 \%$ of available L-malic acid $(3 \mathrm{~g} / l)$ in a synthetic medium (Van Rooyen, 1987). This ability of Saccharomyces yeasts was also recognized by Rankine (1966), who found that these yeasts may metabolize up to $45 \%$ of L- malic acid in grape juice during normal alcoholic fermentation. Carre et al. (1983) reported $11,5 \%$ and $15,2 \%$ utilization of L-malic acid by Sacch. cerevisiae. None of the treatments in Table 2 were as effective as the $L$. oenos induced MLF for malic acid removal. When considering the role of the natural malolactic bacteria in the combined treatments, it can be assumed that they could have enhanced the rate of malic acid removal from half to zero concentration for the L. oenos induced MLF (Table 2).

Chenin blanc 1985: Figure 3 presents the effectivity of utilization of different concentrations of L-malic acid at a fixed $\mathrm{pH}$ of 3,42 by two Schizosaccharomyces spp. It would seem as if an increase in the malic acid concentration stimulated increased utilization, as well as increased rate of removal by both Schizosaccharomyces

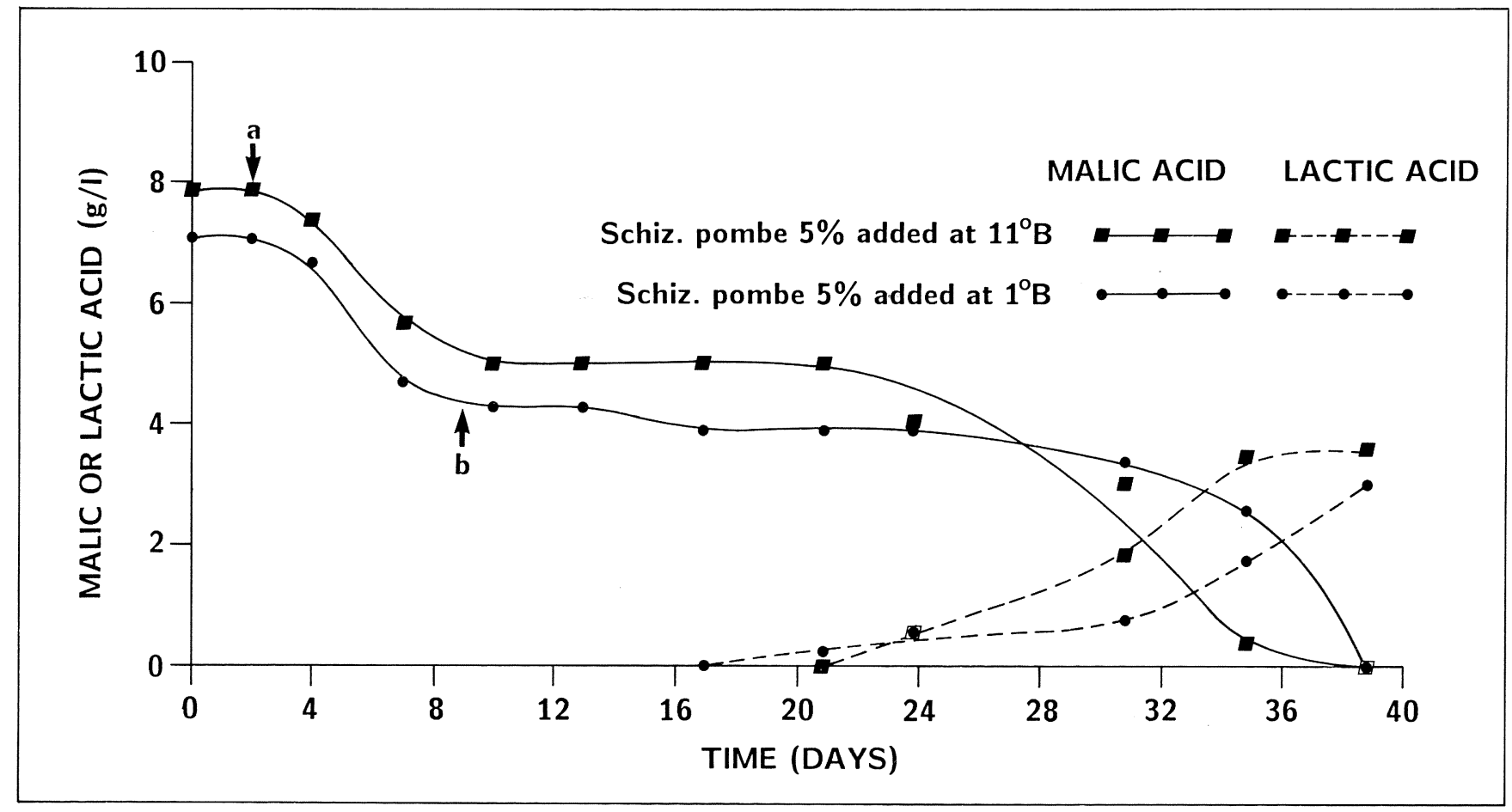

FIG. 2

Concentrations of malic and lactic acids in Cabernet Sauvignon musts fermented by Saccharomyces cerevisiae and inoculated with Schizosaccharomyces pombe at $11^{\circ} \mathrm{B}(\mathrm{a})$ or $1^{\circ} \mathrm{B}(\mathrm{b})$. 


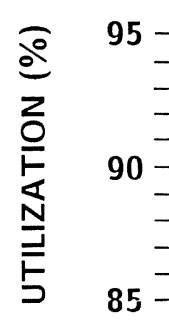

$93.6 \%$

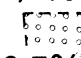

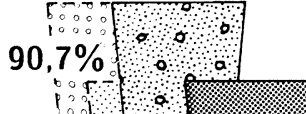

, $7 \%$

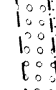

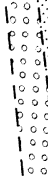

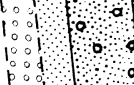

:

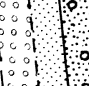

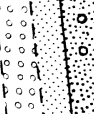

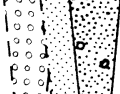

$\begin{array}{lll}0 & 1 \\ 1 & 0 & 0 \\ 1 & 0 & 0\end{array}$

la
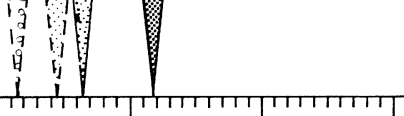

7

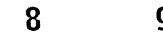

$9 \quad 10$

L-malic 11

aid $(\mathrm{g} / \mathrm{l})$

\section{2}

INITIAL CONCENTRATION

Schiz. pombe

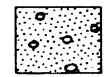

Schiz. malidevorans

UTILIZATION

Schiz. pombe

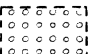

Schiz. malidevorans

FIG. 3

Utilization of different initial concentrations of malic acid by two Schizosaccharomyces spp. in Chenin blanc must.

spp. However, it is evident that the utilization by Schiz. pombe might be inhibited by large amounts of malic acid, as is evident from the drop in percentage utilization from 94,7 to 85,9 . Yang (1973b) indicated an increased percentage utilization by Schiz. pombe of a fixed malic acid content at increased $\mathrm{pH}$ values from 2,5 to 3,5 . Above $\mathrm{pH} 3.0$ malic acid utilization was complete. In musts with high TTA (9.3 and $16.2 \mathrm{~g} / l)$, he reported incomplete malic acid utilization by Schiz. pombe. Except for the $\mathrm{pH}$ dependency, our results indicate that high concentrations of L-malic acid may have an inhibiting effect on the deacidification ability of Schiz. pombe. This was not observed with Schiz. malidevorans (Fig. 3). Different abilities for malic acid utilization between Schiz. pombe and Schiz. malidevorans and also between strains of Schiz. malidevorans, were reported by Rankine (1966). He observed total decomposition of malic acid, independent of $\mathrm{pH}$, by Schiz. malidevorans in musts up to the highest level tested, 116 meq./l $(31,088 \mathrm{~g} / l)$, whereas Schiz. pombe did not show this ability.

\section{Wine Quality:}

Cabernet Sauvignon 1984: Except for the Schiz. malidevorans treatment, wines were of above average quality (Fig. 4). As these results proved the Schiz. pombe treatment was not significantly poorer than the $L$. oenos induced MLF treatment, it was decided to continue thorough experimentation in 1985 to ascertain whether
Schiz. pombe might be used as a substitute for $L$. oenos, both for malic acid removal and for producing wines with comparable quality.

Cabernet Sauvignon 1985: The pure culture Schiz. pombe wines were significantly poorer than those in which spontaneous MLF or induced MLF by L. oenos took place. Figure 4 shows that malic acid removal by induction with different concentrations of Schiz. pombe at different stages during alcoholic fermentation (by Sacch. cerevisiae) had no significantly different effect on wine quality. This corresponds to the observations in Table 2, as these different sizes of Schizosaccharomyces inocula at different stages of fermentation had no marked effect on the time for complete removal of malic acid. A possible tendency could be found between the inocula at $11^{\circ} \mathrm{B}$, that the lower inoculum size had less detrimental effect on wine quality (Fig. 4). This tendency is, however, not forthcoming from the inocula at $1^{\circ} \mathrm{B}$. This could possibly be explained by the length of time during which Schizosaccharomyces could grow and metabolize in the must. The Schizosaccharomyces inocula at $11^{\circ} \mathrm{B}$ were added on the second day after fermentation had been initiated by Sacch. cerevisiae, while the inocula at $1^{\circ} \mathrm{B}$ were added after the fourteenth day.

Several references are made to the fact that Schizosaccharomyces tends to be overgrown by the faster fermenting Saccharomyces at lower temperature (Dit- 


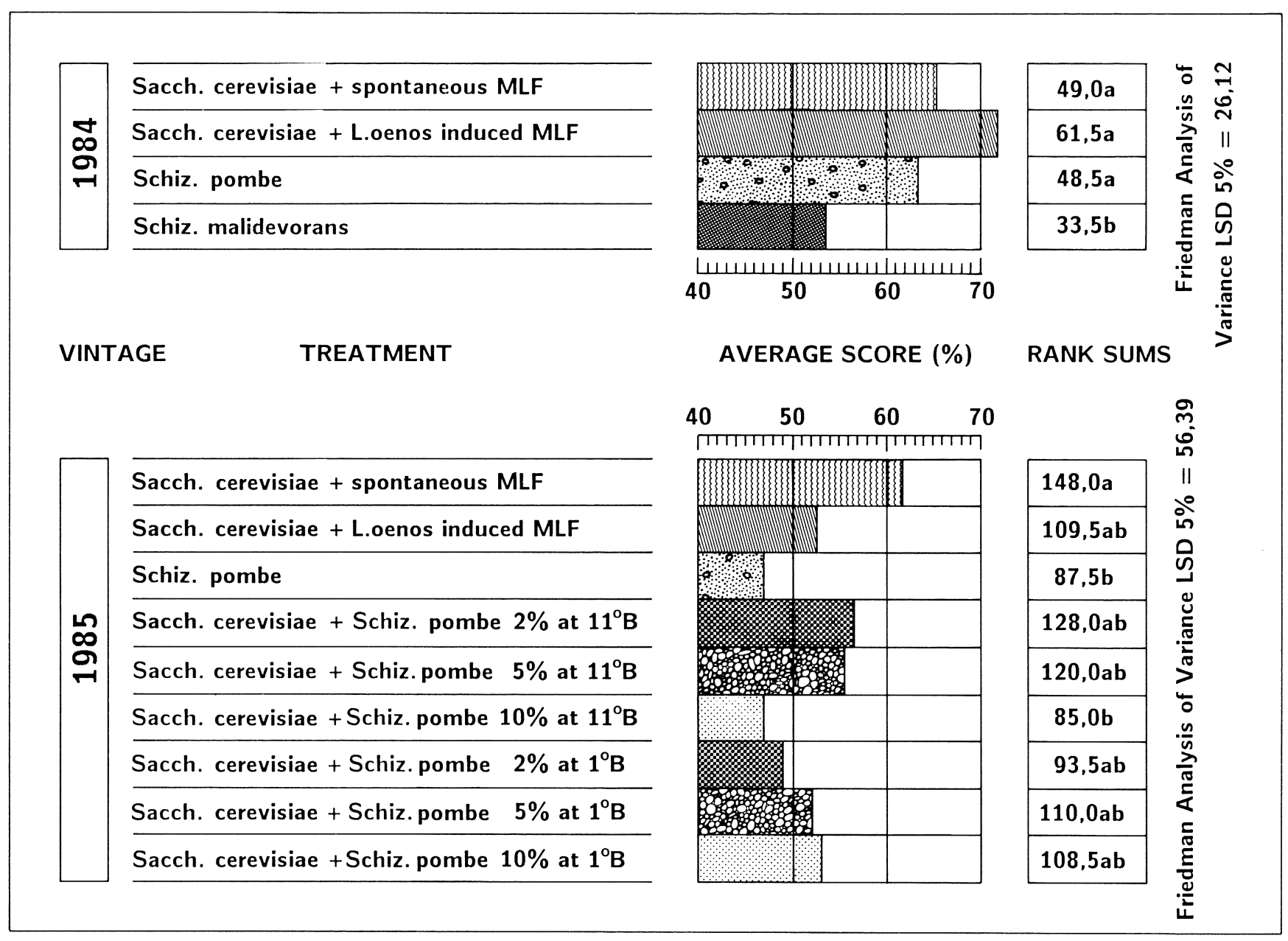

FIG. 4

Effect of different deacidification treatments on wine quality of Cabernet Sauvignon must of two vintages. Rank sums followed by different letters indicate significant differences.

trich, 1963a; Beelman \& Gallander, 1979). One could therefore deduce that Schiz. pombe had not grown to the same extent as the initial inoculum prior to alcoholic fermentation.

It should also be borne in mind that Cabernet Sauvignon, in contrast to Chenin blanc wines, can mask a small amount of malodorous character. Carre et al. (1983) also referred to an attempt to reduce adverse organoleptic effects of Schizosaccharomyces, by addition towards the end of alcoholic fermentation.

Chenin blanc 1985: Considering our observations in the 1984 Cabernet Sauvignon experiment, where the Schiz. pombe treatment did not produce a wine significantly poorer to that of the Schiz. malidevorans, we compared the use of both Schiz. pombe and Schiz. malidevorans to Sacch. cerevisiae in Chenin blanc must. It is important to note that the wines were acidified 24 hours prior to judging (see Materials \& Methods). This was done to ensure that any sensory differences would not be due to lower acidity or higher $\mathrm{pH}$. For the wines fermented by Schiz. pombe and Schiz. malidevorans, the amount of DL-malic acid added was $2,6 \mathrm{~g} / \mathrm{l}$ and $4,2 \mathrm{~g} / \mathrm{l}$ respectively. This is also an added indication of the effectiveness of malic acid removal at the different temperatures. Schiz. malidevorans was included in the white wine quality experiment to determine possible differences inter alia with Schiz. pombe. As is evident from Fig. 5, there was no significant difference in wine quality at $15^{\circ} \mathrm{C}$. The Sacch. cerevisiae wine was significantly better than the two Schizosaccharomyces spp. wines. At $21^{\circ} \mathrm{C}$, however, Schiz. malidevorans produced a significantly poorer wine than Schiz. pombe, whereas the Sacch. cerevisiae wine was significantly better than the Schiz. pombe wine. The higher fermentation temperature $\left(21^{\circ} \mathrm{C}\right)$ illustrates the detrimental effect of Schiz. malidevorans' metabolism versus that of Schiz. pombe. Although $\mathrm{H}_{2} \mathrm{~S}$ was not determined quantitatively, none of the judges commented on the presence of any $\mathrm{H}_{2} \mathrm{~S}$ or sulphury aroma in any of the wines. This contrasts with the findings of $\mathrm{H}_{2} \mathrm{~S}$ produced by Schiz. malidevorans previously reported (Rankine \& Fornachon, 1964; Rankine, 1966).

Quantitative gas chromatographic analysis of volatile wine constituents in the Chenin blanc wines (Table 3 ) indicated that, at $15^{\circ} \mathrm{C}$, (except for ethyl lactate values), Saccharomyces cerevisiae produced higher concentrations of ethyl and acetate esters as well as higher alcohols than both Schiz. pombe and Schiz. malidevo- 
rans. The most marked difference was the higher isoamyl acetate concentration produced by Saccharomyces cerevisiae at both temperatures.

Ethyl lactate values for both Schiz. pombe and Schiz. malidevorans at $15^{\circ} \mathrm{C}$ indicate bacterial metabolism of malic acid, but according to Zeeman, Snyman and Van Wyk (1982), it is doubtful whether this would have had a considerable effect on wine bouquet in view of the odour threshold in wine, as well as its rather neutral smell. Although a particular aroma property can only rarely be associated with a specific ester (Nykänen, 1986), an explanation for the higher sensory quality of Saccharomyces cerevisiae wine at $15^{\circ} \mathrm{C}$ (Fig. 5) could possibly be found in the overall higher values for the measured bouquet substances, as well as specifically the high iso-amyl acetate concentration (Table 3).

Van der Merwe and Van Wyk (1981), who investigated the contribution of fermentation products to the odour of dry white wines, found that addition of certain acetate esters, as a group, to de-aromatized wine caused a highly significant improvement to the odour. The single biggest difference between these Chenin blanc wines seems to have been the lower production of iso-amyl acetate and to a lesser extent hexyl acetate by the Schizosaccharomyces yeasts. The production of ethyl octanoate, which is believed to be a key fermentation volatile (Van der Merwe \& Van Wyk, 1981), was also higher by Sacch. cerevisiae at $15^{\circ} \mathrm{C}$ than by the Schizosaccharomyces yeasts. The overall low production of volatile substances by Saccharomyces at $25^{\circ} \mathrm{C}$ may well have been the reason for the low sensory score.

Carre et al. (1983), reported on the analysis of groups of volatile bouquet substances and found that Schiz. pombe produced much lower concentrations of all these groups (including acetate esters) at $19^{\circ} \mathrm{C}$ than

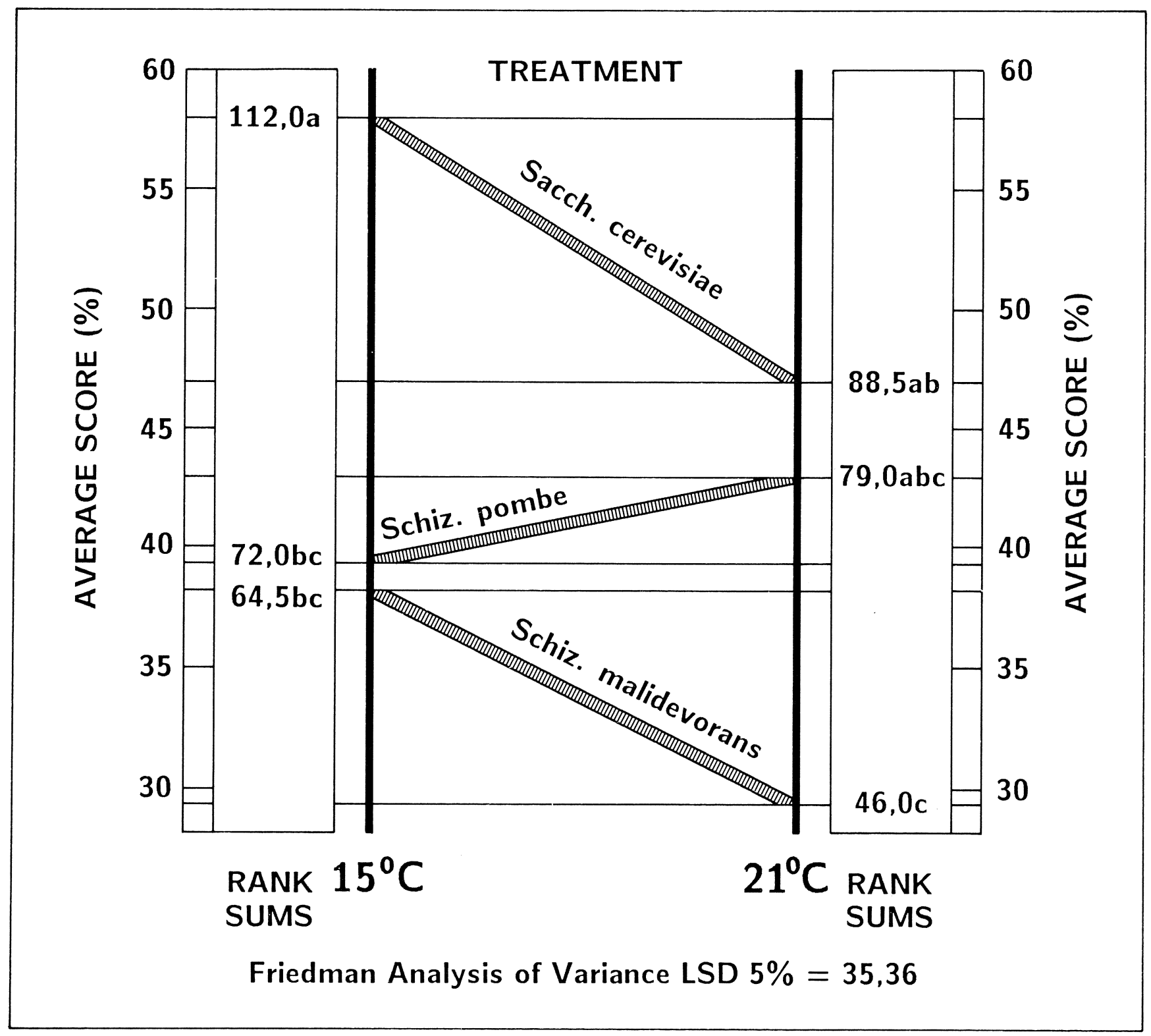

FIG. 5

Effect of yeasts and fermentation temperature on the quality of Chenin blanc wine. Rank sums followed by different letters indicate significant differences. 
TABLE 3

Effect of yeast and temperature on the production of volatile constituents $(\mu \mathrm{g} / l)$ during fermentation in Chenin blanc must.

\begin{tabular}{|c|c|c|c|c|c|c|}
\hline Volatile constituents & $\begin{array}{l}\text { Sacch. } \\
\text { cerevisiae } \\
15^{\circ} \mathrm{C}\end{array}$ & $\begin{array}{l}\text { Schiz. } \\
\text { pombe } \\
15^{\circ} \mathrm{C}\end{array}$ & $\begin{array}{c}\text { Schiz. } \\
\text { malidevorans } \\
15^{\circ} \mathrm{C}\end{array}$ & $\begin{array}{l}\text { Sacch. } \\
\text { cerevisiae } \\
21^{\circ} \mathrm{C}\end{array}$ & $\begin{array}{l}\text { Schiz. } \\
\text { pombe } \\
21^{\circ} \mathrm{C}\end{array}$ & $\begin{array}{c}\text { Schiz. } \\
\text { malidevorans } \\
21^{\circ} \mathrm{C}\end{array}$ \\
\hline $\begin{array}{l}\text { Ethyl hexanoate } \\
\text { Ethyl lactate } \\
\text { Ethyl octanoate } \\
\text { Ethyl decanoate }\end{array}$ & $\begin{array}{r}710.4 \\
2.7 \\
1302.4 \\
208.8\end{array}$ & $\begin{array}{r}758.9 \\
2931.9 \\
1217.7 \\
170.6\end{array}$ & $\begin{array}{r}672.1 \\
3123.0 \\
1128.2 \\
287.9\end{array}$ & $\begin{array}{l}505.9 \\
665.1 \\
692.0 \\
143.6\end{array}$ & $\begin{array}{l}687.4 \\
163.8 \\
997.9 \\
260.6\end{array}$ & $\begin{array}{l}606.7 \\
526.0 \\
940.7 \\
580.7\end{array}$ \\
\hline $\begin{array}{l}\text { i-Amyl acetate } \\
\text { Hexyl acetate } \\
\text { Phenethyl acetate }\end{array}$ & $\begin{array}{r}1417.7 \\
153.5 \\
654.8\end{array}$ & $\begin{array}{r}202.8 \\
113.2 \\
1093.3\end{array}$ & $\begin{array}{r}232.1 \\
11.7 \\
690.1\end{array}$ & $\begin{array}{r}1087.7 \\
91.3 \\
475.5\end{array}$ & $\begin{array}{r}185.2 \\
10.5 \\
904.0\end{array}$ & $\begin{array}{r}483.3 \\
29.0 \\
1262.7\end{array}$ \\
\hline $\begin{array}{l}\text { i-Butyl alcohol } \\
\text { n-Butyl alcohol } \\
\text { i-Amyl alcohol } \\
\text { Hexanol } \\
\text { Phynethyl alcohol }\end{array}$ & $\begin{array}{r}946.9 \\
22.2 \\
39290.6 \\
1348.6 \\
11837.1\end{array}$ & $\begin{array}{r}773.1 \\
20.1 \\
24770.4 \\
1751.8 \\
13786.9\end{array}$ & $\begin{array}{r}385.0 \\
13.0 \\
25908.8 \\
1810.8 \\
7878.8\end{array}$ & $\begin{array}{r}1196.8 \\
31.1 \\
36181.6 \\
713.0 \\
7352.7\end{array}$ & $\begin{array}{r}686.1 \\
19.0 \\
28098.0 \\
1926.5 \\
11959.0\end{array}$ & $\begin{array}{r}1620.5 \\
48.1 \\
31555.3 \\
1744.5 \\
11400.4\end{array}$ \\
\hline $\begin{array}{l}\text { Butyric acid } \\
\text { Hexanoic acid } \\
\text { i-Valeric acid } \\
\text { Octanoic acid } \\
\text { Decanoic acid } \\
\text { Dodecanoic acid }\end{array}$ & $\begin{array}{r}509.6 \\
3864.3 \\
399.8 \\
6841.8 \\
2332.7 \\
74.8\end{array}$ & $\begin{array}{r}341.9 \\
4351.5 \\
397.0 \\
7031.4 \\
2188.3 \\
69.6\end{array}$ & $\begin{array}{r}237.2 \\
3846.0 \\
310.3 \\
5416.9 \\
1860.5 \\
114.6\end{array}$ & $\begin{array}{r}268.6 \\
2596.1 \\
219.6 \\
3838.3 \\
1261.8 \\
44.2\end{array}$ & $\begin{array}{r}220.4 \\
4319.2 \\
318.3 \\
6212.1 \\
1973.2 \\
100.0\end{array}$ & $\begin{array}{r}309.2 \\
3439.1 \\
286.5 \\
5455.0 \\
1664.2 \\
62.6\end{array}$ \\
\hline
\end{tabular}

Sacch. cerevisiae, but did not present any sensory evaluation data. Results of this study confirm these observations.

\section{CONCLUSIONS}

The retarding effect of low temperature on the alcoholic fermentation ability of Schizosaccharomyces pombe and Schiz. malidevorans was such, that growth of naturally occurring malolactic bacteria could commence. Because of the natural microflora occurring on red grapes which are harvested and fermented at relatively high temperatures, bacteria are always potentially active unless specific preventative measures are taken. In such mixed cultures both types of organisms metabolize the malic acid present in the must. It would therefore depend on growth limiting factors such as temperature, acidity and initial inoculum size to what extent one organism would be able to dominate the other.

Although Schiz. pombe seemed to be inhibited by very high concentrations of L-malic acid, even at a fixed $\mathrm{pH}$ of 3,42 , its effectivity would depend on growth conditions. Schiz. malidevorans was most effective in deacidifying low and high L-malic acid concentrations in Chenin blanc musts.

It would seem as if the inability of the Schizosaccharomyces yeasts to produce greater quantities of key fermentation bouquet compounds, could be the major contributing factor to the low sensory quality of such wines.

If fermentation and deacidification is planned with the use of Schizosaccharomyces yeasts, it can be concluded that at the high fermentation temperatures required for complete deacidification, the wine quality will be adversely affected in comparison to the use of Sacch. cerevisiae together with induced MLF by a selected strain of L. oenos.

\section{LITERATURE CITED}

BEELMAN, R.B. \& GALLANDER, J.F., 1979. Wine deacidification. Adv. Food Res. 25, 1-53.

BENDA, I. \& SCHMITT, A. 1969. Untersuchungen zum Säureabbau im Most durch verschiedene Hefestamme aus der Gattung Schizosaccharomyces. Weinberg $u$. Keller 16, 71-83.

BENDA, I. \& SCHMITT, A., 1966. Onologische Untersuchungen zum biologischen Säureabbau im most durch Schizosaccharomyces pombe. Weinberg $u$. Keller 13, 239-254.

CARRE, E., LAFON - LAFOURCADE, S. \& BERTRAND, A., 1983. Desacidification biologique des vins blancs secs par fermentation de l'acide malique par les levures. Connaiss. Vigne $\operatorname{Vin} 17,43-53$

DELFINI, C. \& PAGLIARA, A., 1979. Prove de degradazione biologica dell'ac. malico per fermentazione maloalcolica. Vignevini, (Bologna), 6, 25-30.

DELFINI, C., TORREGGIANI, M.R. \& OTTINA, R., 1983. Fermentazioni maloalcoliche spontane di Schizosaccharomyces nei moste di uve a maturazione precoce del Nord Italia. Vigne - vini 10, 29-38.

DITTRICH, H.H., 1963a. Versuche zum Äpfelsäureabbau mit einer Hefe der Gattung Schizosaccharomyces. Wein - Wiss. 18, 392405.

DITTRICH, H.H., 1963b. Zum chemismus des Äpfelsäureabbaues mit einer Hefe der Gattung Schizosaccharomyces. Wein - Wiss. 18, 406-410.

ETHIRAJ, S. \& SURESH, E.R., 1978. Deacidification of high acid grape musts and wine making with Schizosaccharomyces pombe. J. Fd. Sci. Technol. 15, 111-113.

ETHIRAJ, S., SURESH, E.R. \& ONKARAYYA, H., 1983. Controlled deacidification of "Bangalore Blue" grape must with Schizosaccharomyces pombe. J. Fd. Sci. Technol. 20, 248-250.

KUNKEE, R.E., 1968. Simplified chromatographic procedure for detection of malolactic fermentation. Wines \& Vines 49, 23-24.

MARAIS, J., 1986. A reproducible capillary gas chromatographic technique for the determination of specific terpenes in grape juice and wine. S. Afr. J. Enol. Vitic. 7, 21-25.

MARESCALCHI, C., 1974. Biological deacidification of wines using Schizosaccharomyces. Ital. Vinic. Agrar. 64, 470. (Microbiol. Abstr. 10, 10A5416).

MAYER, K., 1963. Biologischer Äpfelsäurreabbau mit Spalthefen. Schweizer. Ztschr.f. Obst-u. Weinbau. 72, 564-566.

MUNYON, J.R. \& NAGEL, C.W., 1977. Comparison of methods of deacidification of musts and wines. Am. J. Enol. Vitic. 28, 7987. 
NYKÄNEN, L., 1986. Formation and occurrence of flavor compounds in wine and distilled alcoholic beverages. Am. J. Enol. Vitic. 37, 84-96.

RANKINE, B.C. \& FORNACHON, J.C.M., 1964. Schizosaccharomyces malidevorans sp.n., a yeast decomposing L-malic acid. Antonie van Leeuwenhoek 30, 73-75.

RANKINE, B.C., 1966. Decomposition of L-malic acid by wine yeasts. J. Sci. Fd. Agric. 17, 312-316.

SCHWARZENBACH, R., 1982. High performance liquid chromatography of carboxylic acids. J. Chrom. 251, 339-558.

SPIROV, N., PIPERKOVA, R., KALKOVA, N. \& VASILEVA, N., 1982. Biological deacidification of white table wines by Schizosaccharomyces yeasts. Logarstvo $i$ Vinarstvo. 31, 27-29 (Abstr. FSTA 15 7H976).

SVEJCAR, V., 1970. Ausnutzung von Schizosaccharomyces beim biologischen Säureaubbau. Wein - Wiss. 25, 1-5.

TROMP, A. \& CONRADIE, W.J., 1979. An effective scoring system for the sensory evaluation of experimental wines $A m$. J. Enol. Vitic. 30, 278-283.
VAN DER MERWE, C.A. \& VAN WYK, C.J., 1981. The contribution of some fermentation products to the odor of dry white wines. Am. J. Enol. Vitic. 32, 41-46.

VAN ROOYEN, T.J., 1987. Unpublished data.

VAN ROOYEN, T.J. \& VAN WYK, C.J., 1986. A rapid and quantitative HPLC method for determination of diethylene glycol. $S$. Afr. J. Enol. Vitic. 7, 36-38.

VAN WYK, C.J., 1976. Malo-lactic fermentation in South African table wines. Am. J. Enol. Vitic. 27, 181-185.

VAN ZYL, J.A. \& DU PLESSIS, L. DE W., 1961. The microbiology of South African winemaking. Part I. The yeasts occurring in vineyards, musts and wines. S. Afr. J. Agr. Sci. 4, 393-403.

YANG, H.Y., 1973a. Deacidification of grape musts with Schizosaccharomyces pombe. Am. J. Enol. Vitic. 24, 1-4.

YANG, H.Y., 1973b. Effect of $\mathrm{pH}$ on the activity of Schizosaccharomyces pombe. J. Food Sci. 38, 1156-1157.

ZEEMAN, W., SNYMAN, J.P. \& VAN WYK, C.J., 1982. The influence of yeast strain and malolactic fermentation on some volatile bouquet substances and on quality of table wines. Proc. Grape and Wine Centennial, Univ. California, Davis. 79-90. 